\title{
Importance of Fish Antimicrobial Peptides for Aquaculture and Biomedicine
}

\section{Francesco Buonocore}

Department for Innovation in Biological, Agro-food and Forest systems (DIBAF), University of Tuscia, Largo dell'Università s.n.c., I-01100 Viterbo, Italy.

Fishes rely heavily on their innate immune defences for initial protection against pathogen agents invasion, both during the first stages of their lives, when the adaptive immunity is still not active, and when they are completely developed, as the adaptive immune system display scarce memory and short-lived secondary responses [1]. The antimicrobial peptides (AMPs) are one of the major components of the innate defences in protecting from such infections. In mammals, AMPs typically have broad-spectrum antimicrobial activity, they can often kill multiple pathogens that include bacteria, fungi, parasites and viruses. A large number of AMPs have been isolated from a wide number of fish species during last years, among which pleurocidin from winter flounder (Pleuronectes americanus) [2], cathelicidins from rainbow trout (Oncorhynchus mykiss) [3], defensins from zebrafish (Danio rerio) [4], piscidins from hybrid striped bass (white bass, Morone chrysops, female, $\mathrm{x}$ striped bass, Morone saxatilis, male) [5], dicentracin from sea bass (Dicentrarchus labrax) [6], and hepcidin from channel catfish (Ictalurus punctatus) [7], epinecidin from the grouper (Epinephelus coiodes) [8] (for a review see [9]). The activity of fish AMPs have been tested not only against the more common fish bacterial pathogens $[8,10]$ but either against other pathogens like nervous necrosis virus [11]. Moreover, some AMPs have shown dual functional aspects, like hepcidins that have been indicated to be involved in iron regulation [12]. Piscidins have been demonstrated to be present both in mast cells and professional phagocytic granulocytes [13] and have been detected via bug blot, Western blot, ELISA and/or immunochemistry in gill extract of different important fish species [14].

Therefore, due to their impact for fish immune system, AMPs levels could be useful to determine, maintain or improve fish health in aquaculture [15]. In fact, as an example, piscidin 2 estimated concentrations in different tissues of hybrid striped bass are lethal to different ectoparasites [16] and piscidin 4 concentrations in gills are lethal to important bacterial pathogens [17]. Different chronic stresses lead to significant down-regulation of AMPs and thus their monitoring could be useful in aquaculture to measure health status and, on the contrary, up-regulation of AMPs could be of interest to enhance disease resistance and to improve the efficacy of traditional treatments against pathogens, like it happens for immunostimulant [15]. AMPs could be of great interest even in biomedicine, as they are attractive candidates for different therapeutic approaches. In mammals, AMPs have demonstrated diverse biologic effects [18], like enodotoxin neutralization, immunomodulating activity and induction of angiogenesis and, therefore, they are seen as very attractive therapeutic tools. At the moment, the increasing incidence of antibiotic-resistant bacterial infections is of great importance in medicine and AMPs could help to cope this challenge. They can combat different pathogens and exert their biologic activity in several ways due to their multifunctional properties [18] and, therefore, the research in this field is growing very fast during the last years.

\section{References}

1. Du Pasquier $L$ (2001) The immune system of invertebrates and vertebrates. Comp Biochem Physiol B Biochem Mol Biol 129: 1-15.
2. Cole AM, Weis P, Diamond G (1997) Isolation and characterization of pleurocidin, an antimicrobial peptide in the skin secretions of winter flounder. J Biol Chem 272: 12008-12013.

3. Chang Cl, Pleguezuelos O, Zhang YA, Zou J, Secombes CJ (2005) Identification of a novel cathelicidin gene in the rainbow trout, Oncorhynchus mykiss. Infect Immun 73: 5053-5064.

4. Zou J, Mercier C, Koussounadis A, Secombes C (2007) Discovery of multiple beta-defensin like homologues in teleost fish. Mol Immunol 44: 638-647.

5. Silphaduang U, Noga EJ (2001) Peptide antibiotics in mast cells of fish. Nature 414: 268-269

6. Salerno G, Parrinello N, Roch P, Cammarata M (2007) cDNA sequence and tissue expression of an antimicrobial peptide, dicentracin; a new component of the moronecidin family isolated from head kidney leukocytes of sea bass, Dicentrarchus labrax. Comp Biochem Physiol B Biochem Mol Biol, Part B 146: 521-529.

7. Bao B, Peatman E, Li P, He C, Liu Z (2005) Catfish hepcidin gene is expressed in a wide range of tissues and exhibits tissue-specific up-regulation after bacterial infection. Dev Comp Immunol 29: 939-950.

8. Pan CY, Chen JY, Cheng YSE, Chen CY, Ni IH, et al. (2007) Gene expression and localization of the epinecidin-1 antimicrobial peptide in the grouper (Epinephelus coiodes), and its role in protecting fish against pathogenic infection. DNA Cell Biol 26: 403-413.

9. Ravichandran S, Kumaravel K, Rameshkumar G, AjithKumar TT (2010) Antimicrobial peptides from the marine fishes. Res J Immunol 3: 146-156.

10. Noga EJ, Silphaduang U, Park NG, Seo JK, Stephenson J, et al. (2009) Piscidin 4, a novel member of the piscidin family of antimicrobial peptides. Comp Biochem Physiol, Part B 152: 299-305.

11. Chia TJ, Wu YC, Chen JY, Chi SC (2010) Antimicrobial peptides (AMP) with antiviral activity against fish nodavirus. Fish Shellfish Immunol 28: 434-439.

12. Shi J, Camus AC (2006) Hepcidin in amphibian and fishes: antimicrobial peptides or iron regulatory hormones. Dev Comp Immunol 30: 746-755.

13. Mulero I, Noga EJ, Meseguer J, Garcia-Ayala A, Mulero V (2008) The antimicrobial peptides piscidins are stored in the granules of professional phagocytic granulocytes of fish and are delivered to the bacteria-containing phagosome upon phagocytosis. Dev Comp Immunol 32: 1531-1538.

14. Corrales J, Mulero I, Mulero V, Noga EJ (2010) Detection of antimicrobial peptides related to piscidin 4 in important aquacultured fish. Dev Comp Immunol 34: 331-343.

15. Noga EJ, Ullal AJ, Corrales J, Fernandes JMO (2011)Application of antimicrobia polipeptide host defenses to aquaculture: exploitation of downregulation and upregulation responses. Comp Biochem Physiol, Part D 6: 44-54.

16. Colorni A, Ullal A, Heinsch G, Noga EJ (2008) Activity of the antimicrobia polypeptide piscidin 2 against fish ectoparasites. J Fish Dis 31: 423-432.

${ }^{*}$ Corresponding author: Dr. Francesco Buonocore, Department for Innovation in Biological, Agro-food and Forest systems (DIBAF), University of Tuscia, Largo dell'Università s.n.c., I-01100 Viterbo, Italy, Phone +39-0761-357644, Fax. +390761-357179; E-mail: fbuono@unitus.it

Received September 02, 2011; Accepted October 18, 2011; Published October 21, 2011

Citation: Buonocore F (2011) Importance of Fish Antimicrobial Peptides for Aquaculture and Biomedicine. J Aquac Res Development 2:105e. doi:10.4172/21559546.1000105e

Copyright: (c) 2011 Buonocore F. This is an open-access article distributed under the terms of the Creative Commons Attribution License, which permits unrestricted use, distribution, and reproduction in any medium, provided the original author and source are credited. 
Citation: Buonocore F (2011) Importance of Fish Antimicrobial Peptides for Aquaculture and Biomedicine. J Aquac Res Development 2:105e. doi:10.4172/2155-9546.1000105e

Page 2 of 2

17. Corrales J, Gordon WL, Noga EJ (2009) Development of an ELISA for quantification of the antimicrobial peptide piscidin 4 and its application to assess stress in fish. Fish Shellfish Immunol 27: 154-163.
18. Guani-Guerra E, Santos-Mendoza T, Lugo-Reyes SO, Teran LM (2010) Antimicrobial peptides: general overview and clinical implications in human health and disease. Clin Immunol 135: 1-11. 